\title{
THE IMPORTANCE OF SCHOOL LIBRARY IN GIRL-CHILD EDUCATION WITH SPECIAL REFERENCE TO NORTHERN NIGERIA
}

\author{
BY
}

\author{
MARTHA JAMOK ELISHA \\ KIL, ABU, ZARIA
}

\begin{abstract}
This paper highlights some problems affecting the education of the girl child in northern Nigeria. It emphasizes the role of the library and government in developing the girl child. It also highlights areas where the library can support the girl - child education and how it can enhance reading habit among children by providing relevant information. It ends with recommendations that will help make school libraries relevant in nation building and the creation of professional capabilities among females.
\end{abstract}

\section{INTRODUCTION}

Education in the 21 century is considered as the main key to the development of all Nations. Education performs a major role in equipping the individual with the skills and knowledge that he needs for economic development. In other words, education helps to prepare a person for participation in economic development and viewing education as that process that helps to develop the whole man physically, mentally, morally, politically, socially and technologically to enable him function effectively in any environment in which he may find himself. The importance of education in the lives of individuals cannot be overemphasized. United Nation Children Fund (1990) stated that although the proportion of educated children is on the increase, boys have faired much better than girls and the same discrepancy increases during the secondary phase. This fact is also supported by the result of the 1991 census in Nigeria. There is a clamour world over recently for the education of the girl-child who is our tomorrow's mother. This is in recognition of the fact that education of a girl child is one of the only ways of empowering the woman to enable her emancipate herself from the shackles of socioeconomic and cultural defection. Every successful educational programme in any society must depend on certain variables among which are the availability of textbooks, non-book materials and other educative sources. A country can be developed only when the potential of its citizens are utilized. Education is considered as the right for all in any society in respective of their gender, socio-economic and political status as well as cultural background.

In view of this, the federal government of Nigeria organized the national policy on education in 1981 and laid emphasis on the importance of the school library as an integral part of the educational development of the child in the $3^{\text {rd }}$ edition of the 1988, which status:
"Libraries are one of the most important educational services. Every state ministry of education needs to provide funds for the establishment of libraries in all our educational institution and to train librarians and library assistants for services".

In any educational set-up apart from human resources, books and other reading materials are considered as major material resources that are required in the process of attaining educational goals.

Girl- child education which is the focus of this study touches on fundamental issues of gender parity which is both age long and global. Today, not only in Northern Nigeria, but also in other parts of the world is the agitation for female education. This is to enable her get equal right, dignity and education as the male counterparts.

The girl child often faces discrimination from the earliest stage of life through childhood and into adulthood. Her low status is reflected in the denial of her fundamental needs and rights. Early marriage, domestic abuse, sexual exploitation, discrimination, less access to education are some of the woes that do befall the female child in northern Nigeria.

\section{The Girl-Child and the State of Education in Northern Nigeria}

A simple working definition of the child is that given by UNICEF (1995) which reads "any human being below eighteen (18) years”. Furthermore UNICEF (1997) gave another comprehensive definition of children as "people below the age of eighteen whose best interest must be taken into account in all situations. By implication, these definitions use chronological/age as a yard stick to determine who a child is. Furthermore, no matter what a child has to be protected at all cost, most particularly from the time of birth to above eighteen years. Every opportunity should be given to the girl-child to gain 
equal status and treatment to grow and develop to her full potentials in every nation.

All the lofty ideas (equal opportunity to education etc) as presented in the national policy on education and in the Nigerian constitution are mere rhetoric in the life of the girl-child because instead of going to school like her male counterparts, she is being used as a baby sitter, she is exposed to sexual harassment, early marriage, street hawking and all sort of danger at the detriment of her education. The national policy on education which Nigeria has since 1981 has not been implemented effectively and efficiently due to rapid population growth, insufficient political will, a long period of undemocratic governance and mostly poor management of her resources. Girls in northern Nigeria are most affected by these negative factors. Statistics have shown that western part of the country is leading in terms of educational advancement while the north is far behind.

Adeyanju (2005) noted that girls in Nigeria are disadvantaged in their access to education as such all do not register for school, those that register are not regular and eventually dropout in the north, the number of children out of school is high and the proportion of girls to boys in school ranges from 1 girls to 2 boys and even $1-3$ in some states.

The United Nation committees on the right of the child, in an observation of the report submitted by Nigeria, expressed some concern that universal education has not been realized in Nigeria partially because it is neither free nor compulsory, despite the constitutional guarantee. They observed the high illiteracy among girls and women and the gender and regional disparities in school enrolment. Anammah (1995) noted that traditionally, the girl child is regarded as the weaker sex, in an effort to protect her, she is always deprived and exploited. Statistics have shown that the enrolment gap between boys and girls in primary and secondary schools continue to remain wide in some northern states. More girls are dropping out of school, while more parents are still withdrawing their girls from school or withholding them from going to school. Generally, culture not only defines the place of women separately but also put a lot of stumbling blocks on their way. In some cultures, it is believed that the girl child and later woman should be confined to the kitchen and she is socialized into accepting her traditional role of child bearing and rearing educating her therefore need not go beyond preparing her in such traditional roles of wife and mother. If and when she finds herself in school her role in the house affects her performance and subsequently her attainment in society.

Also, a greater percentage of Nigerians are living well below the poverty line, the economy then becomes determinant factor in sending children to schools and since male preference is some how accepted in parts of northern Nigeria, parents some times withdraw their girls from school to be married out, to enable them sponsor the boys to complete their education because they are being considered to be the bread winners.

Western education was viewed with suspicion until recently particularly in the north, and where parent were compelled to sent their children to school, only the boys were allowed to go basically because they considered it as a threat to female chastity, delay in marriage, fear of being converted to Christianity and also fear that educated girls may not be submissive.

In 2003, the Ministry of Education adopted the strategy for accelerating girls education in Nigeria. In 2004, the Ministry also launched girls education project supported by UNICEF in order to focus interventions on states with lowest enrolment rate of girls. The universal basic education commission has been implementing projects that provide more schools, better qualified teachers and gender sensitive books and curriculum.

Inspite of tremendous progress made, there are still major challenges facing the country in achieving gender equality in education and female empowerment. The attainment of education for all is constrained by the high rate of attrition in primary and secondary schools which is due to many factors including:

i. Engagement in income generating activities by some children during school hours

ii. Ill-health arising from poor environmental sanitation, lack of portable water, lack of toilet facilities etc.

iii. Religions and cultural factors which cause some parents to choose religions schools in preference to western schools.

iv. Early marriage of girls and teenage pregnancy.

v. Inaccessible location of schools from children

vi.

In Nigeria where nearly half of its population (47\%), 1991 census is women, neglecting the education of the girl child will be an unaffordable risk. The girl child is the life wire of the entire household. No wonder, Bellamy, (1985) Executive Director of UNICEF stated in clear terms that 'there can be no significant or sustainable transformation in societies and no significant reduction in poverty until girls receive the quality basic education they need, to take their rightful place as equal partners in development. Women are therefore society's most important resource managers, they perform up to $80 \%$ of work in running the household including food supply in most African countries. Bellamy 
concluded that girl child education is a necessity if any significant development is to be recorded.

\section{The importance of School Libraries in girl-child education}

School library is a collection of wide varieties of learning materials housed in school (primary, secondary or teachers college), organized by professional staff and made available for use by both teachers and students. Library materials include books, periodicals, pamphlets, map and illustrations, films, filmstrip, slide and tapes. Johnson O. and Lanre (2002).

Boman (1999) noted that the library should not be seen as a place where books are kept, it means more than that. It is a system designed to preserve and facilitate the use of graphic records to fill the missing links in any communication process. Mohammed (1998) submits that it is no longer fashionable to talk of school library, but instructional materials Center (IMC) Educational Resources Center (ERC) and workshop for the subjects of the school curriculum. Some factors responsible for the new designation is that documents in modern times are electronically produced instead of the traditional printed matter. Electronic production of materials is obviously better than the traditional printing in terms of portability, usability, space for storage or convenience.

2. The ideal library collection is more than books, journals and newspapers, there are films, cassettes, slides and computer softwares.

\section{OBJECTIVES OF A SCHOOL LIBRARY}

It is necessary to identify some of the objectives of a library in school setting. A clear knowledge of these objectives will help people of to know the role the school library can play in the education of the girl child especially in the north.

Amune and Dauda (2001) stated that school library is established in order to:

i. Support and enrich the curriculum which the school operates.

ii. Provide basic collections that will help to broaden the learners educational experiences beyond the limit of its classroom experience,

iii. Motivate the learner to read for pleasure and not only for his assignments to be submitted at a given time or a test and examination to write,

iv. Cultivate the habit of inquisitive reading in the student whether or not the teacher ask him to do.

v. Provide teachers with a variety of resource materials that will help them prepare their classroom lessons. vi. Keep teachers and students informed of latest development in their subject areas

vii. And teach library users how to respect public property, the rights of others and how to take care of books and keep then from tearing. The library role in achieving the objectives of education can not be overemphasized. Libraries are no longer mere store houses of books. They are libraries for making teaching and learning very effective.

Libraries are not only reading rooms but are research centers in schools. School libraries that are equipped with current and relevant material are great assets to educational programmes. Aina (1991) observed that one of the purpose of the school/college library is to work with teachers in the selection and use of all types of library materials which contribute to teaching programme.

Johnson and Lanre (2002) said that the library contributes to education in a number of ways such as:

1. Encouraging reading

2. expanding learning process

3. developing learning skills

4. developing appreciation, attitude and value and

5. assisting with development task. Malumfashi (1991) in the same view noted that a typical school library purpose is to facilitate the pupils acquisition of knowledge and also ease the teachers effort in educating them as well as improving themselves intellectually across the board.

The resources of a school library are largely relevant to the curriculum including anticipated and special needs of the school. Noncurriculum based items are also provided for broadening their capabilities. This means that the purpose of school library is not only to provide avenue for the pupils and teachers alike to use books for independent study and research but for providing individuals with factual knowledge plus that literacy appreciation needed for intelligent decisions in life.

Girls today must have basic information if they must succeed in life. To educate a woman means educating the whole nation. The library can help the girl child develop confidence in her selfworth and faith in her ability to cope with challenges of life. The school library can arouse the interest and satisfy the curiosity of the girl child by providing adequate information that concern her person, search for why the clamour for an egalitarian society or why the clamour for a change in her traditional roles of "mothering" and "wifing". 
As important as school libraries are to our educational system they are still in deplorable condition, Anamma (1995) confirmed this in her study of some school libraries, stated that our school libraries are nothing to write home about, where there are school libraries, the materials are not there.

Okiy (2004) stated that the inculcation of the habit of using multimedia school libraries will act as a catalyst to ensure that the education obtained by these girls is of high quality. The students will be well grounded in the art of using libraries from a very early age, into higher education than more educated and capable women will be produced to fill the vacum already created in important societal jobs. Educated women will make better contribution to national development, and they will also participate actively in the political activities of the country and hence provide stiffer competition with men who have always dominated the Nigerian politics. They will patronize libraries for useful information to constantly update themselves with current information.

\section{Responsibility of Northern Government}

The government also has an important role to play in promoting girl-child education and social awareness by initiating and promoting policies geared at liberating the girl child from the shackles of a male oriented civilization. Zamfara and Kano state government (2003) now have an educational board for females. Beyond this, the states took over the payment of teaching and non teaching staff salary of all girls in the local primary schools under the board. The government also made provisions of breakfast to every pupil and this has greatly improved the enrolment and retention of must girls. Books, instructional materials, uniforms etc are provided by government. Northern government and leaders must show greater commitment solving the problem and stop paying lip service to it.

Government should strive to eradicate illiteracy by ensuring free primary and secondary education to some girls in the north. It should also direct its policy towards ensuring equal and adequate educational opportunities at all levels.

Government should have a policy of stopping parents from withdrawing or with holding their girls from going to school.

Most public schools in north are seriously neglected and only few private schools have good school libraries with adequate and relevant resources to meet the information needs of children. The national policy on education stated that government should provide enough funds to ensure that schools are properly equipped with suitable libraries to promote sound and effective teaching, but this has never been implemented UNESCO (2001) stated that school library should equip children with life long learning skills enabling them to live as responsible citizens. The government should not hesitate in spending funds to develop school and public libraries in the country/

\section{CONCLUSION}

From the foregoing, we can see that the library can assist in solving the problem of the girlchild education by introducing reading habit to her and also inform and educate the society. The educational gap between the North and the south cannot be bridged until the problem of the girlchild education is effectively tackled. The role of school library in information provision cannot be overemphasized.

\section{RECOMMENDATION}

1. Schools and public libraries should identify and uphold both fictional and historical heroes and models that the girl child can look up to and emulate.

2. The library should also get materials that are focused on promoting the development of the girl child personality, talents and mental as well as physical abilities to their fullest potentials.

3. Northern government should make effort to reduce the number of female students who drop out and provide programmes for those who left school prematurely. Women should have the same opportunity to benefit from scholarships and other study grants.

4. Other states in the north should emulate Zamfara and Kano states government by establishing Education Board for females.

5. Government should ensure that schools have functional libraries, adequate and suitable learning materials. Special grant should also be made available to improve school libraries.

\section{REFERENCES}

Adeyenju, F.B. (2005) Girl child education and National development New Nigeria Weekly, 9 July Pg. 16 - 17.

Aina, O.I. (1998) "Women culture and Society”. In Nigeria women society and Development. Edited by Sesary A or Olabiui a. (1999) Ibadan. Dokun RU. House.

Anammah, D.C. (1995) "Survival of the girl-child, problems and prospects. Nigerian 
Association.

Amune S.A. \& Daudu H.M. (2001) New approach to successful school library services in the new millennium for effective implementation of universal Basic Education. Communicate: Journal of Library and Information Science. Vol. 3 No. 5. $1 \& 2$ pg $20-25$.

Bellamy, C. (1995) Women and the environment Poor planet. UNEP Publishers, Nairobi Kenya. Vol. 7. Pg 7-8.

Boman, D.D. (1999) Introducing the library to Nigerian Students Pankshin Academic Trust Fund P. 1.

Johnson O \& Lanre, M.A. (2002) The relevance of school library in the provision of education in Nigeria: COMMUNICATE: Journal of Library and Information Science vol. 4 No. 1 and 2 Pg. $43-49$.

Kano State Female Education Board (2004).

Malumfashi, M.A. (1991) 'Primary Education and School Libraries in Nigeria: Implication for Education for All”. Lagos Text and Leisure Publishers pg. 127 - 129.

Millennium, Development Goals Report (2004) Nigeria Pg. 22-31.

Mohammed, S. I. (1998) "Gender disparity in Education in the Norther States of Nigeria", cited in Educational Renaissance in Northern Nigeria ed. By Sani, H.A. (1998) Okene Desmond Tutu Pub.

Nigerian Federal Ministry of Education (1981) National Policy on Education; Lagos, Federal Ministry of Education, Pg. 49.

Nigerian Federal Ministry, Population Head Count Census (1991).

Okiy, R.B. (2004) The Universal Basic Education Programme and the Development of School Libraries in Nigeria: a catalyst for greater female participation in National development. Information Development. SAGE Publication vol. 20 No. 1

UNESCO School Library Manifesto (2001) “The school library in Teaching and Learning for All”.

United Nation Children Fund Policy Review (1990 - 1997). Strategies for children in the 1990s.
Zamfara State Female Education Board Gusau (2003). 